\title{
PAPER
}

\section{Evidence for the role of demyelination, HLA-DR alleles, and cytokines in the pathogenesis of parvovirus B 19 meningoencephalitis and its sequelae}

\author{
J R Kerr, F Barah, M L Chiswick, G V McDonnell, J Smith, M D Chapman, J B Bingham, \\ P Kelleher, M N Sheppard
}

J Neurol Neurosurg Psychiatry 2002;73:739-746

See end of article for authors' affiliations

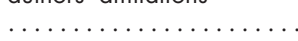

Correspondence to: Dr J R Kerr, Department of Microbiology, Royal Brompton Hospital, Imperial College of Science, Technology and Medicine, Sydney Street, London SW3 6NP, UK; i.kerr@ic.ac.uk

Received 15 April 2002 In revised form 7 August 2002

Accepted 15 August 2002

\begin{abstract}
Objective: To review the clinical and pathological features of parvovirus B19 meningoencephalitis and its sequelae in 12 previously published cases, and to perform additional tests to determine the pathogenesis of the disease.

Methods: Cases were reviewed and available serum and cerebrospinal fluid (CSF) tested for antiganglioside antibodies and a range of cytokines. In situ hybridisation for parvovirus B19 DNA was performed on postmortem brain tissue in two cases. HLA-DRB 1 typing was undertaken on genomic DNA extracted from peripheral blood leucocytes.

Results: Cerebellar involvement was suggested either clinically or pathologically in four cases. In the two cases with postmortem histology, there was marked atrophy of the molecular and granular layers of the cerebellum with focal loss of Purkinje cells. Brain scanning by MRI or CT was done in six cases during the acute phase. Three were abnormal with evidence of demyelination. Three had markedly enlarged ventricles, in two of which there was high signal intensity from the white matter on both T1 and T2 weighted images. The three cases with abnormal brain scans had long term neurological sequelae (mental retardation, personality change, altered affect). In situ hybridisation on available postmortem brain tissue was negative in the two cases tested. All cases in which HLA-DR alleles were determined carried at least one of the following alleles: HLA-DRB 1*01, ${ }^{*} 04,{ }^{*} 07,{ }^{*} 09,{ }^{*} 15,{ }^{*} 16$. Available serum and CSF was tested for antiganglioside antibodies (all negative) and for a panel of cytokines, which had a similar profile in both serum $(n=5)$ and CSF $(n=1)$ during the acute phase. Cytokines that were consistently detectable were IL-6 (mean $726.20 \mathrm{pg} / \mathrm{ml}), \mathrm{TNF} \alpha(50.64 \mathrm{pg} / \mathrm{ml})$, IFN $\gamma(39.64 \mathrm{pg} / \mathrm{ml})$, GM-CSF (216.12 pg/ml), and MCP-1 (154.43 pg/ml); IL-1 $\beta$, IL-5, and IL-13 were undetectable.

Conclusions: HLA-DR associations, an increased cytokine response, and benefit from immunomodulatory treatment (in one case) support a role for the immune response in the pathogenesis of parvovirus B19 meningoencephalitis.
\end{abstract}

M eningoencephalitis associated with acute infection by human parvovirus B19 is not uncommon, particularly during years of peak incidence of infection. We have previously estimated that the incidence of undiagnosed meningoencephalitis that can be attributed to parvovirus B19 infection during an outbreak year in the United Kingdom is $4.3 \%{ }^{1}$ This is the largest case series to date on parvovirus B19 meningoencephalitis.

In order to characterise these cases further we have documented the clinical presentation and the radiological and histopathological findings, and have undertaken further tests in these patients to determine the pathogenesis of the disease and its neurological sequelae.

\section{METHODS \\ Patients}

Twelve cases of B19 meningoencephalitis were the focus of this study. These were detected by examining CSF from cases of undiagnosed meningoencephalitis for B19 DNA by two nested polymerase chain reaction (PCR) assays. Details of the cases and procedures have been described previously. ${ }^{1}$ Case numbers are the same in the two studies. The ages of the patients ranged from one day to 15 years, with a female to male ratio of 1:1 (table 1). Clinical histories and results of laboratory testing were obtained from the case notes (table 1). Case histories are outlined in the Results section.

\section{Antiganglioside antibodies}

Autoantibodies against CNS tissue-for example, the gangliosides-occur in patients with connective tissue diseases and are associated with neurological involvement. ${ }^{2}$ As parvovirus B19 has also been associated with a variety of connective tissue diseases and autoimmunity, we hypothesised that such a mechanism may account for neurological illness in certain cases. Samples were screened for the presence of immunoglobulins $\mathrm{G}$ and $\mathrm{M}$ (IgG and IgM) against the glycolipids GMl, GDla, GTlb, GQ1b, and sulphatides according to recognised guidelines. All antigens were supplied by Sigma UK (Watford, Hertfordshire, UK) except GQlb, which was obtained from Calbiochem (San Diego, California, USA).

Antigens were reconstituted in ethanol, except GTIb which was reconstituted in methanol, before being diluted $1 / 100$ in ethanol. A $25 \mu \mathrm{l}$ aliquot of antigen was placed in each well of a Maxisorp 96 well microtitre plate (Nunc, Wiesbaden, Germany). Each antigen was placed in two adjacent columns along with an ethanol blank. The ethanol was evaporated at room temperature, after which the wells were blocked with $250 \mu \mathrm{l}$ of $10 \%$ normal rabbit serum (NRS) in phosphate buffered saline (PBS) for two hours. Samples were diluted 1/1000 in block solution, incubated for 30 minutes at room temperature, and $100 \mu \mathrm{l}$ of sample added to each well. The plate was covered in Clingfilm and incubated overnight at $4^{\circ} \mathrm{C}$.

The wells were washed six times with $200 \mu \mathrm{l}$ of $1 \%$ NRS in PBS before incubation with $100 \mu \mathrm{l}$ of a mixture of antihuman 
Table 1 Clinical information and HLA-DRB 1 alleles in 12 cases of B 19 meningoencephalitis

\begin{tabular}{|c|c|c|c|c|c|c|c|c|}
\hline No & Sex & Age (gest) & Symptoms and signs $\dagger$ & EEG result & $\begin{array}{l}\text { Brain scan } \\
\text { (CT/MR) }\end{array}$ & Death & Sequelae & $\begin{array}{l}\text { HLA-DRB1 } \\
\text { alleles }\end{array}$ \\
\hline 1 & M & $2 \mathrm{~m}$ & $\begin{array}{l}\text { Meningitis, pyrexia, URTI, anaemia (Hb } 8.8 \\
\text { g/dl) }\end{array}$ & ND & - & $\mathrm{N}$ & $\mathrm{N}$ & ${ }^{\star} 04 /{ }^{*} 14$ \\
\hline 2 & M & $2 \mathrm{~m}$ & Encephalitis, conjunctivitis, URTI & Normal & $M R$, normal & $\mathrm{N}$ & $\mathrm{N}$ & *13/*15 \\
\hline 3 & M & $6 \mathrm{~m}$ & $\begin{array}{l}\text { Meningitis, pyrexia, hepatosplenomegaly, } \\
\text { cervical lymphadenopathy, pancytopenia, } \\
\text { anaemia }(\mathrm{Hb} 8.5 \mathrm{~g} / \mathrm{dll}) \text {, prolonged clotting } \\
\text { time, hepatitis, } \mathrm{HLH}\end{array}$ & ND & - & Y & - & - \\
\hline 4 & M & $2 y, 1 \mathrm{~m}$ & Encephalitis, pyrexia, cALL & Encephalopathic & MR, abnormal & $\mathrm{N}$ & Y & *04 \\
\hline 5 & $\mathrm{~F}$ & $2 y, 3 m$ & $\begin{array}{l}\text { Encephalitis, ataxia, anaemia (Hb } 10.9 \\
\mathrm{~g} / \mathrm{dl}) \text {, hepatitis }\end{array}$ & Encephalopathic & $\mathrm{CT}$, normal & $\mathrm{N}$ & $\mathrm{N}$ & ${ }^{\star} 04 /{ }^{*} 07$ \\
\hline 6 & $\mathrm{~F}$ & $6 y, 4 \mathrm{~m}$ & $\begin{array}{l}\text { Encephalitis, thrombocytopenia, hepatitis, } \\
\text { DIC, acute renal failure, multiple organ } \\
\text { failure, Cockayne syndrome }\end{array}$ & Silence & - & Y & - & - \\
\hline 7 & M & $9 y$ & $\begin{array}{l}\text { Encephalitis, thrombocytopenia, anaemia (Hb } \\
10.7 \mathrm{~g} / \mathrm{dll}) \text {, cervical lymphadenopathy }\end{array}$ & Encephalopathic & MR, abnormal & $\mathrm{N}$ & Y & - \\
\hline 8 & $\mathrm{~F}$ & $13 y$ & $\begin{array}{l}\text { Encephalitis, liver failure, Crigler-Naijar } \\
\text { syndrome }\end{array}$ & ND & - & ND & ND & - \\
\hline 9 & M & $13 y$ & Encephalitis, hemiparesis, ataxia & $\begin{array}{l}\text { Post-ictal EEG: slow } \\
\text { on left }\end{array}$ & $\mathrm{MR}+\mathrm{CT}$, normal & $\mathrm{N}$ & $\mathrm{N}$ & - \\
\hline 10 & $\mathrm{~F}$ & $15 y$ & Encephalitis & Encephalopathic & $\mathrm{CT}$, abnormal & $\mathrm{N}$ & Y & ${ }^{*} 03 /{ }^{*} 04$ \\
\hline 11 & $\mathrm{~F}$ & $1 \mathrm{~d}(23 \mathrm{wk})$ & $\begin{array}{l}\text { Encephalitis, NEC, PDA, hepatitis, surfactant } \\
\text { deficiency, osteopenia of immaturity, valgus } \\
\text { leg deformity at age } 1 \text { y }\end{array}$ & ND & - & $\mathrm{N}$ & Y & - \\
\hline 12 & $\mathrm{~F}$ & $1 \mathrm{~d}(36 \mathrm{wk})$ & $\begin{array}{l}\text { Encephalitis, VSD, ASD, PDA, poor } \\
\text { respiratory drive, obstructive jaundice, } \\
\text { persistent anaemia, } 47 X X X\end{array}$ & ND & $\begin{array}{l}\text { [USS, cysts on } \\
\text { choroid plexus] }\end{array}$ & Y & - & - \\
\hline
\end{tabular}

The twin of case 11 was born with "cerebral palsy" consisting of right sided hemiplegia, deafness in the right ear, and poor control of the right eye. This baby also had seizures and surfactant deficient lung disease.

†Published previously.'

ASD, atrial septal defect; cALL, common acute lymphoblastic leukaemia; d, day; DIC, disseminated intravascular coagulation; F, female; gest, gestation; $\mathrm{HLH}$, haemophagocytic lymphohistiocytosis (diagnosed both antemortem (bone marrow) and postmortem); m, month; $M$, male; N, no; ND, not determined; NEC, necrotising enterocolitis, PDA, patent ductus arteriosus; URTI, upper respiratory tract infection; USS, ultrasound scan; VSD, ventricular septal defect; wk, week; $y$, year; $Y$, yes.

IgG F(ab) and antihuman IgM, both conjugated to horse radish peroxidase, diluted $1 / 1000$ in wash solution, for one hour. After six washes, the presence of antiglycolipid antibodies was detected with $100 \mu \mathrm{l}$ of freshly prepared colour reagent $(10 \mathrm{mg}$ $o$-phenylenediamine in $10 \mathrm{ml} 0.05 \mathrm{M}$ acetate buffer with $12 \mu \mathrm{l}$ $30 \%$ hydrogen peroxide added). The colour reaction was stopped after 15 minutes by adding $50 \mu \mathrm{l} \mathrm{l}$ M hydrochloric acid and the intensity read on an ELISA reader at $490 \mathrm{~nm}$, blanked at $405 \mathrm{~nm}$. A positive result was considered to be any sample that had an average net absorbance of more than 0.5 for a particular antigen.

\section{Cytokine/chemokine testing}

A panel of cytokines was quantitated in available serum and CSF specimens from the cases and in serum from 19 normal healthy adult controls. These were measured in duplicate using the Bioplex Protein Array system (BioRad, Hemel Hempstead, Hertfordshire, UK), according to the manufacturer's instructions. This is a novel multiplexed, particle based, flow cytometric assay which uses specific monoclonal antibodies linked to microspheres incorporating distinct proportions of two fluorescent dyes. The particular value of this assay in the present study was its ability to quantify several mediators in a sample volume as small as $15 \mu$ l. Our assay was customised to detect and quantify tumour necrosis factor $\alpha(\mathrm{TNF} \alpha), \gamma$ interferon (IFN $\gamma$ ), interleukin-1 $\beta$ (IL-1 $\beta$ ), interleukin-5 (IL-5), interleukin-6 (IL-6), interleukin-13 (IL-13), granulocyte-macrophage colony stimulating factor (GM-CSF), and macrophage chemoattractant protein-1 (MCP-1). Mediators were included in this assay according to present knowledge of those upregulated during B19 infection. $^{3}$

\section{HLA-DR testing}

HLA alleles were determined by hybridisation of sequence specific oligonucleotide probes (SSOP) to human genomic DNA extracted from whole blood.

\section{In situ hybridisation}

Formalin fixed, paraffin embedded neural tissue blocks were cut into $5 \mu \mathrm{m}$ sections, from which paraffin wax was removed by incubation in xylene for 20 minutes, fresh xylene for 10 minutes, and $100 \%$ ethanol for 10 minutes. The sections were then immersed in fresh $100 \%$ ethanol for five minutes, followed by rehydration through graded alcohol over 10 minutes $(75 \%, 50 \%$, and $25 \%$ ethanol), and finally immersed in fresh distilled water for five minutes. Rehydrated sections were immersed in $0.02 \mathrm{~N} \mathrm{HCl}$ for 10 minutes, washed in PBS, immersed in PBS with $0.01 \%$ Triton X-100 for three minutes, and again washed in PBS. Sections were then covered with $100 \mu \mathrm{l} \mathrm{of} 2.5 \mu \mathrm{g} / \mathrm{ml}$ pepsin in $0.01 \mathrm{~N} \mathrm{HCl}$ at $37^{\circ} \mathrm{C}$ for 50 minutes and washed in PBS with $2 \mathrm{mg} / \mathrm{ml}$ glycine to stop proteolysis. After washing, dehydration, and air drying, sections were irradiated using a microwave oven in $0.01 \mathrm{M} \mathrm{MgCl}_{2}$ for 10 minutes.

A biotin labelled probe was prepared from almost the entire coding sequence of human parvovirus B19 strain $\mathrm{Stu}^{4}$ cloned into plasmid pGEM-1 (obtained as a gift from Dr J P Clewley, Central Public Health Laboratory, Colindale, London, UK) using the BioNick ${ }^{\mathrm{TM}}$ labelling system. Hybridisation was performed using $\mathrm{Bl} 9$ probe $(200 \mathrm{ng} / \mathrm{ml})$ in $50 \mu \mathrm{l}$ of the hybridisation buffer $(50 \%$ ( $\mathrm{vol} / \mathrm{vol})$ of formamide, $20 \times \mathrm{SSC}$ ( $\mathrm{NaCl} /$ sodium citrate), 5\% (wt/vol) dextran sulphate, $0.5 \mathrm{mM}$ ethylenediaminetetraacetic acid (EDTA), $1 \mathrm{mM}$ Tris-HCl pH $7.3,0.02 \mathrm{~g}$ skimmed milk) at $37^{\circ} \mathrm{C}$ for 24 hours, after an initial denaturation step of $94^{\circ} \mathrm{C}$ for 10 minutes.

After hybridisation, stringency washes were applied as follows: $20 \times$ SSC for five minutes at room temperature and 10 minutes at $60^{\circ} \mathrm{C}, 0.2 \times$ SSC for two minutes at room temperature and 10 minutes at $42^{\circ} \mathrm{C}$, and a final wash in $0.1 \times$ SSC at room temperature for two minutes. The sections were incubated in buffer 2 (buffer 1 with $0.02 \mathrm{~g}$ of the skimmed milk) at $37^{\circ} \mathrm{C}$ for 30 minutes, then covered with $150 \mu \mathrm{l}$ of streptavidin alkaline phosphatase conjugate diluted at 1.5:1000 in buffer 1 (0.1 M Tris- $\mathrm{HCl} \mathrm{pH} \mathrm{7.4,} \mathrm{0.1} \mathrm{M} \mathrm{NaCl,} 2 \mathrm{mM}$ 


\begin{tabular}{|c|c|c|c|c|c|}
\hline No & Sample & $\begin{array}{l}\text { Sample time (days } \\
\text { post onset) }\end{array}$ & $\begin{array}{l}\text { CSF leucocytes } \\
\left(/ \mathrm{mm}^{3}\right)\end{array}$ & B19 NS1 PCR† & $\begin{array}{l}\text { B19 DNA } \\
\text { in situ } \\
\text { hybridisation } \\
\text { on brain tissue }\end{array}$ \\
\hline \multirow[t]{2}{*}{1} & CSF & 3 & $13(80 \% \mathrm{~m})$ & + & \\
\hline & Serum & 15 & & + & \\
\hline \multirow[t]{3}{*}{2} & CSF & 3 & NA & + & \\
\hline & Serum & 8 & & - & \\
\hline & Serum & 15 & & - & \\
\hline 3 & CSF & 7 & 75 (90\% I) & + & - \\
\hline 4 & CSF & 2 & $2(100 \% \mathrm{~m})$ & + & \\
\hline 5 & CSF & 6 & 1 & + & \\
\hline 6 & CSF & necropsy & NA & + & - \\
\hline \multirow[t]{2}{*}{7} & CSF & 14 & NA & + & \\
\hline & Serum & 13 & & + & \\
\hline 8 & CSF & 4 & NA & + & \\
\hline 9 & CSF & 5 & 0 & + & \\
\hline 10 & CSF & 4 & $60(80 \% 1)$ & + & \\
\hline \multirow[t]{3}{*}{11} & CSF & 4 & 14 & + & \\
\hline & CSF & 6 & 0 & + & \\
\hline & Serum & 2 & & + & \\
\hline 12 & CSF & 20 & 13 & + & \\
\hline
\end{tabular}

$\mathrm{MgCl}_{2}$ ) and incubated at room temperature for 15 minutes. The slides were then washed in buffer 1 for five minutes and in buffer 3 for a further five minutes. The slides were incubated in dye solution containing $132 \mu \mathrm{l}$ of nitro-blue tetrazolium and $100 \mu \mathrm{l}$ of 5-bromo,4-chloro,3-indolyl phosphate in $30 \mathrm{ml}$ of buffer $3(0.1 \mathrm{M}$ Tris- $\mathrm{HCl}, \mathrm{pH} 9.5,0.1 \mathrm{M} \mathrm{NaCl}$, $50 \mathrm{mM} \mathrm{MgCl}$ ), for 30 minutes to two hours at $37^{\circ} \mathrm{C}$ in the dark.

After colour development, slides were washed, dried, mounted, and examined by light microscopy. Positive results were scored when dark blue to purple staining was clearly seen. Positive and negative controls were employed throughout. The positive control was B19 infected fetal heart which was positive by immunocytochemistry for B19 capsid antigen. The negative control was lung tissue from a three month old girl who died of generalised infection with Streptococcus pyogenes.

\section{RESULTS}

\section{Patients}

Clinical details on each of the 12 patients with parvovirus B19 meningoencephalitis are summarised in table 1. B19 markers and CSF microscopy are shown in table 2 .

\section{Case 1}

A previously well two month old boy admitted with a fever, cough, upper respiratory tract infection, poor feeding, irritability, and drowsiness. This boy's mother also complained of a self limiting flu-like illness 48 hours before his admission; however, no such prodrome occurred in the patient. On admission, peripheral blood examination showed a haemoglobin of $8.8 \mathrm{~g} / \mathrm{dl}$, a white cell count of $13.7 \times 10^{9} / 1$ (51\% neutrophils, 37\% lymphocytes, 9\% monocytes), and a platelet count of $444 \times 10^{9} / \mathrm{l}$. CSF examination on day 3 after admission showed 13 white cells $/ \mathrm{mm}^{3}$ (20\% polymorphonuclear and $80 \%$ mononuclear cells), and no red cells; no bacteria were seen on Gram stain, and bacterial culture was negative; virus culture was also negative. He was treated with intravenous cefotaxime, made a good recovery, and was discharged on day five. Subsequently, he has been in good health and has no recognisable deficit resulting from this illness. CSF (day 3) and serum (day 15; taken after discharge) both tested positive for B19 DNA. CSF was weakly positive for
anti-B19 IgM and strongly positive for anti-B19 IgG. Serum (day 15) was positive for both anti-B19 IgM and IgG.

\section{Case 2}

A previously well two month old boy was admitted with a gradual onset of lethargy, drowsiness, myoclonic jerks, and nystagmus. Two weeks earlier he had had an episode of self limited upper respiratory tract infection and conjunctivitis. No other family members were affected. An EEG was normal. Magnetic resonance imaging (MRI) showed high signal intensity from the white matter; however, this was thought to be normal for his age. The scan was otherwise normal. CSF was taken on day 3 after admission but it was blood stained and unsuitable for microscopic analysis. It was negative on bacterial culture. He was initially thought to have Kinsbourne's encephalitis and was treated with steroids, with improvement. However, seizures persisted following discharge and on day 40 postadmission he was started on a five day course of intravenous immunoglobulin which was curative. Subsequently, he has been in good health and has no recognisable deficit resulting from this illness. CSF (day 3 post admission) was positive for B19 DNA and anti-B19IgG. Sera (days 8 and 15 postadmission, respectively) were negative for B19 DNA. Serum on day 8 was weakly positive for anti-B19 IgM and negative for anti-B19 IgG. Serum on day 15 was weakly positive for both anti-B19 IgM and IgG.

\section{Case 3}

A previously well six month old boy whose parents were first cousins was admitted with a three week history of intermittent pyrexia, lethargy, and poor feeding. On examination he had hepatosplenomegaly, left cervical lymphadenopathy, and neck stiffness. Examination of peripheral blood showed a haemoglobin of $8.5 \mathrm{~g} / \mathrm{dl}$, a white cell count of $5.6 \times 10^{9} / 1$ with a normal differential, a platelet count of $14 \times 10^{9} / \mathrm{l}$, mildly raised alanine transaminase and aspartate transaminase, a marginally prolonged activated partial thromboplastin time (APTT) of 39 seconds, and a borderline low fibrinogen of $1.1 \mathrm{~g} / \mathrm{dl}$. CSF showed a protein of $2.8 \mathrm{~g} / \mathrm{dl}$, glucose of $2 \mathrm{mmol} / \mathrm{l}$ (blood glucose, 4.7 $\mathrm{mmol} / \mathrm{l}), 75$ white cells $/ \mathrm{mm}^{3}$ (90\% lymphocytes); no organisms were seen on Gram stain or cultured, while PCR for herpes simplex virus (HSV) was negative. A bone marrow aspirate showed occasional cells with evidence of erythrophagocytosis. Treatment consisted of intravenous fluids, cefotaxime, acyclovir, and 

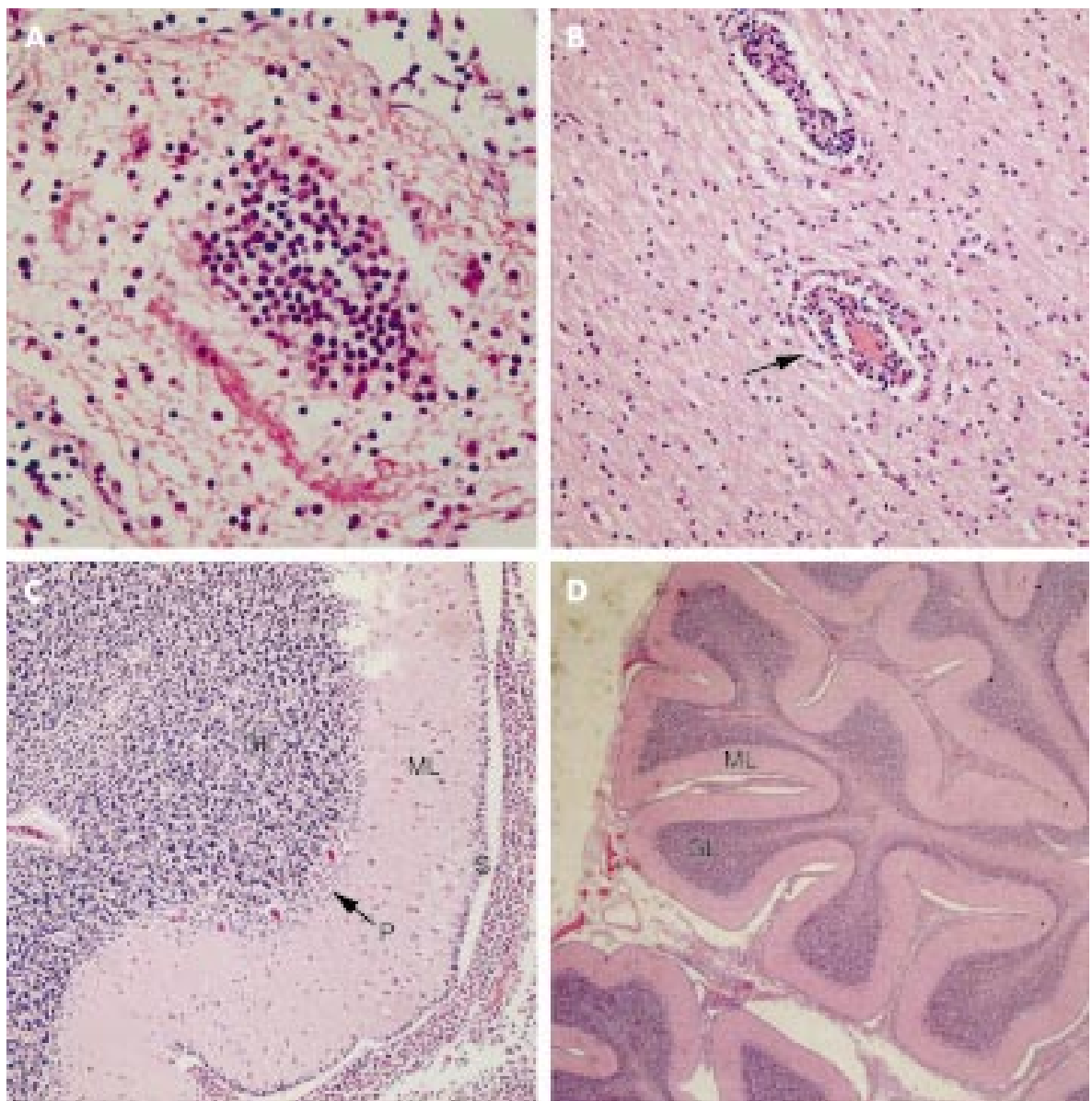

Figure 1 (A) A lymphohistiocytic infiltrate within the cerebellar leptomeninges. (B) Perivascular lymphohistiocytic infiltrate within the cerebellar leptomeninges. (C) Cerebellum, showing a marked focally dense histiocytic infiltrate on the surface (S) of the molecular layer (ML) associated with loss of Purkinje cells (P) and thinning of both the external granular layer (GL) and molecular layer (ML). (D) Cerebellum, showing thinning of the external granular layer (GL) and molecular layer (ML).

empirical therapy for tuberculosis. However, on day 8 following admission, he had a respiratory arrest and exploratory thoracocentesis revealed a massive haemothorax. Resuscitation was unsuccessful. CSF (day 7) was positive for B19 DNA, and weakly positive for both anti-B19 IgM and IgG. Serum was unavailable for testing.

Necropsy examination revealed widespread systemic infiltration by lymphocytes and macrophages showing haemophagocytosis (haemophagocytic lymphohistiocytosis) affecting the dura, leptomeninges, brain, lung, liver, thymus, spleen, and bone marrow. Macroscopically, the central nervous system (CNS) was unremarkable. Microscopically, a patchy lymphohistiocytic infiltrate was observed on the dura, with scant haemophagocytosis. The leptomeninges also featured this infiltrate, which was focally marked with prominent haemophagocytosis in the cerebellum. The infiltrate was observed to extend along the Virchow-Robin spaces and was present in perivascular distribution within the parenchyma. Changes were present in the forebrain, brain stem, cerebellum, and spinal cord. The molecular layer of the cerebellum featured a focally dense histiocytic infiltrate associated with loss of Purkinje cells and thinning of both the molecular and external granular layers (fig 1, panels A-D).

\section{Case 4}

A two year old boy was admitted with encephalopathy during a relapse of common acute lymphoblastic leukaemia (ALL). Common ALL had been diagnosed at 11 months of age and remission achieved on the MRC infant ALL protocol. However, he suffered a CNS and bone marrow relapse 13 months later, when aged two years. Just before this admission he had had a Hickman line inserted, developed a haemothorax, and had been transfused with one unit of packed red cells. He then became pyrexial and irritable, and had episodes of stiffness during which his plantar reflexes became extensor. CSF examination showed a white cell count of $2 \times 10^{9} / 1$ mononuclear cells, no red cells, and no lymphoblasts; no organisms were seen on Gram stain or cultured; PCR for HSV was negative. There were non-specific changes of encephalopathy on EEG, and MRI showed wide subarachnoid spaces, enlarged ventricles, and an increased signal from white matter in both $\mathrm{Tl}$ and T2 weighted scans (fig 2, panels A and B). This illness lasted 7-10 days and then gradually resolved. However, although he currently has no residual physical neurological deficit, he is significantly delayed. For example, at the age of five years he was not toilet trained and had a few solitary words only. Psychological testing revealed marked global deficits. CSF taken on day 2 was positive for B19 DNA and negative for both anti-B19 IgM and IgG. Serum was unavailable for testing.

\section{Case 5}

A previously well two year old girl was admitted with sudden onset of pallor, ataxia, and falling to her left side followed by tonic/clonic seizures. She was managed with diazepam, acyclovir, and ceftriaxone. EEG was encephalopathic and computed tomography (CT) of the skull was normal. Examination of peripheral blood showed a haemoglobin of $10.9 \mathrm{~g} / \mathrm{dl}$, a white cell count of $11.4 \times 10^{9} / 1(59 \%$ neutrophils, $32 \%$ lymphocytes), and an alkaline phosphatase of 1291 

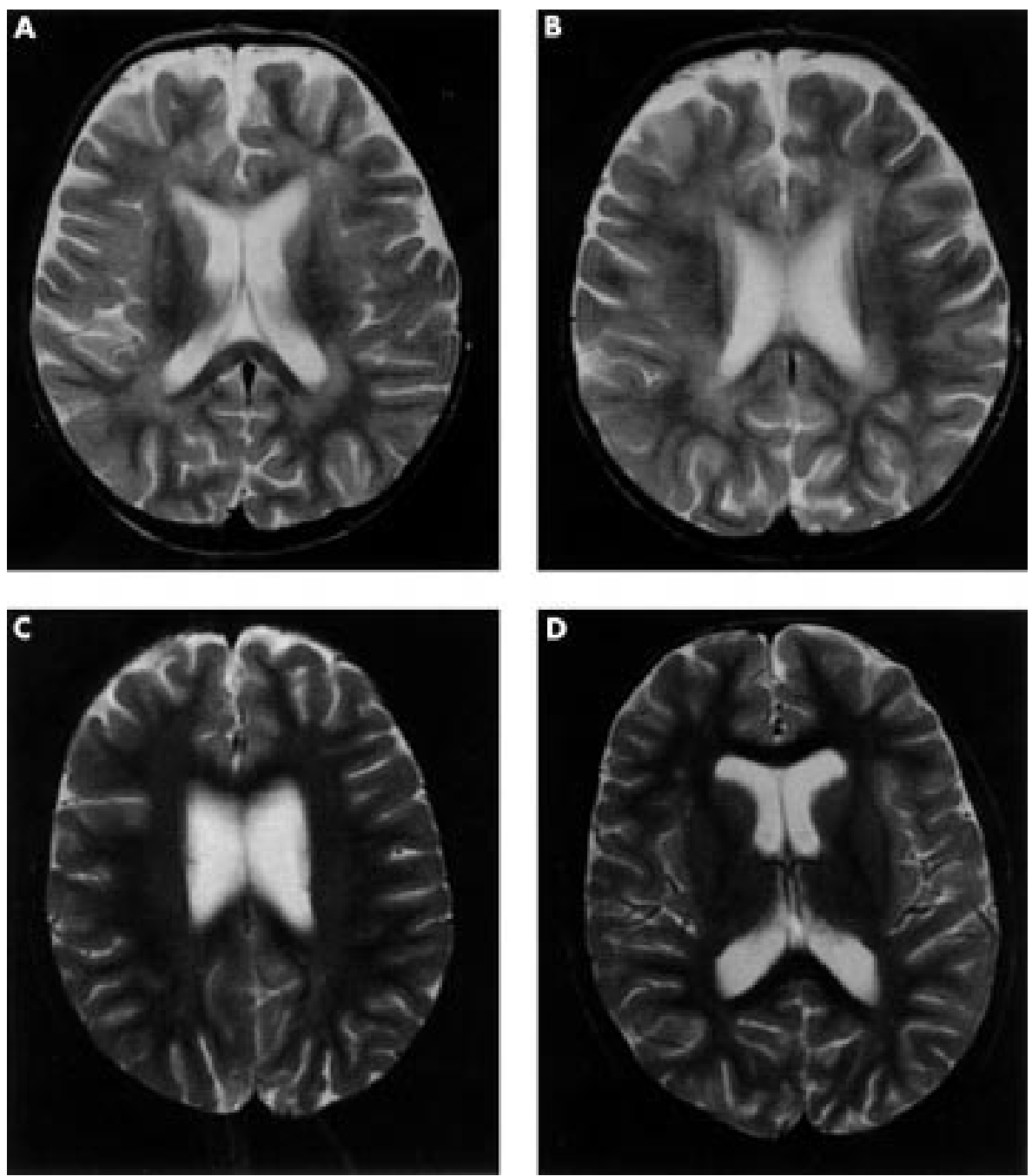

Figure 2 T2 weighted magnetic resonance imaging of the head in cases 4 (panels A and B) and 7 (panels C and D), showing enlarged ventricles and high signal intensity within the white matter.

mmol/l. CSF examination showed a white cell count of $1 / \mathrm{mm}^{3}$ and a red cell count of less than $1 / \mathrm{mm}^{3}$; no organisms were seen on Gram stain or cultured; PCR for HSV was negative. She recovered quickly and has subsequently been developmentally normal. Her temperature was normal throughout this illness. There was no previous history of seizures and there was no family history of seizures. CSF (day 6) was positive for B19 DNA and negative for both anti-B19 IgM and IgG. Serum was unavailable for testing.

\section{Case 6}

A six year old girl was admitted with acute onset of abdominal pain, lethargy, and fever. Her parents were first cousins and she had failed to thrive since birth. At the age of four years, she had kyphoscoliosis, spastic diplegia, and gastro-oesophageal reflux, managed with fundoplication and gastrostomy. Cockayne's syndrome had been suspected and was confirmed by skin culture studies. She had an emergency laparotomy which identified a small bowel obstruction. On day 2, she developed thrombocytopenia and disseminated intravascular coagulation (DIC) and was given fresh frozen plasma. On day 6 , she had acute renal failure, oedema, hepatic dysfunction, paralytic ileus, and right upper lobe collapse and consolidation. An EEG showed a complete absence of activity and she was pronounced dead as a result of multiple organ failure on day 8 following admission.
Necropsy examination showed slightly dysmorphic features with sunken eyes and microcephaly. Peripheral oedema was present, with puffy hands and feet. Both kidneys were underweight (R, $37 \mathrm{~g}$ (normal, $68 \mathrm{~g}$ ); L, $32 \mathrm{~g}$ (normal, $64 \mathrm{~g}$ )). The liver was underweight ( $260 \mathrm{~g}$ (normal, $642 \mathrm{~g})$ ), pale yellow in colour, and abnormally soft. The thymus was light and showed atrophy. Focal lung oedema and focal alveolar haemorrhage were present. Brain, and particularly the cerebellum, was underweight (562 g unfixed (normal, $1273 \mathrm{~g}$ )); the cerebellum and brain stem weighed $49 \mathrm{~g}$. On section, cerebral white matter was markedly abnormal with generalised loss of substance and patchy demyelination. The lateral ventricles were increased in size. The mid-brain aqueduct was large. In the brain stem, the clear demarcation between white and grey matter was lost. There was cerebellar cortical atrophy with focal loss of Purkinje and granular cells. Foci of calcification were present in the cerebellar white matter and cortex. Vessel walls in the cerebellar white matter showed extensive calcification. Within the cerebral cortex there was neuronal loss with focal calcification. Calcification was also present in the subcortical white matter and blood vessel walls. Reactive astrocytes were seen in the periventricular white matter. CSF taken at necropsy, although negative in virus culture, was positive for B19 DNA, but negative for both anti-B19 IgM and IgG. Serum was unavailable for testing. 


\section{Case 7}

A nine year old boy was admitted with tonic/clonic seizures which had been preceded for a few days by headache, cervical lymphadenopathy, and vomiting. Seizures increased in frequency and he was started on phenytoin and continuous clonazepam infusion, and managed in a paediatric intensive care unit. He was also treated with cefotaxime, acyclovir, and erythromycin. An EEG showed generalised non-specific activity consistent with encephalitis.

MRI showed grossly enlarged ventricles (fig 2, panels C and D), small focal abnormalities in the right frontal white matter, focal abnormalities in the Virchow-Robin spaces, and increased signal from the white matter, which was particularly prominent in the parietal lobes in both $\mathrm{T} 1$ and $\mathrm{T} 2$ weighted scans (fig 2, panels C and D). DNA testing for fragile X chromosome was negative.

Peripheral blood examination showed a haemoglobin of $10.7 \mathrm{~g} / \mathrm{dl}$, a white cell count of $21.7 \times 10^{\circ} / \mathrm{l}$, and a platelet count of $518 \times 10^{9} / \mathrm{l}$. CSF (day 14 postadmission) tested negative by PCR for HSV, varicella-zoster virus (VZV), enterovirus, and cytomegalovirus DNA; it was positive for B19 DNA but negative for anti-B19 IgG and IgM. Serum (day 13) was positive for B19 DNA and anti-B19 IgM, but negative for anti-B19 IgG.

Although he survived this illness, he had significant neurological sequelae. Comprehensive cognitive assessment at three and six months after the onset of the illness showed verbal and performance scores well below average, with a verbal IQ of 73 and a performance IQ of 78. He had particular weaknesses in understanding words, performing tasks in response to auditory cues, short term memory, and motor coordination. Before this episode he had been placid, but following it he became unpredictable and at times aggressive and violent. He also had several readmissions for convulsions and is now maintained on long term anticonvulsant treatment.

\section{Case 8}

A girl aged 13 years presented with cholestasis and liver failure secondary to Crigler-Najjar syndrome type II. This responded to barbiturates and although she was scheduled for liver transplantation, her liver failure improved and she was discharged. An acute episode of meningoencephalitis developed while she was in hospital, and CSF taken at this time tested positive for B19 DNA; there was insufficient sample to test for B19 antibodies. She was discharged but died several months later.

\section{Case 9}

A 13 year old boy presented with headache, decreased appetite, hyperreflexia, seizures, right focal signs, right hemiparesis, and ataxia. Lymphadenopathy was also noted. Brain scans (CT and MRI) were normal. An EEG performed postseizure showed slowing on the left. CSF analysis revealed $0.4 \mathrm{~g} / \mathrm{l}$ protein, glucose $3.5 \mathrm{mmol} / \mathrm{l}$ (plasma $4.7 \mathrm{mmol} / \mathrm{l}$ ), and no cells. The encephalitis recovered spontaneously but for two weeks he had a strange affect, with incoordination and ataxia. Headaches persisted for a further two weeks and then resolved without sequelae. A lymph node biopsy taken during the acute phase showed granulomatous lymphadenitis. CSF taken on day 5 tested positive for B19 DNA but there was insufficient sample to test for B19 antibodies.

\section{Case 10}

A previously healthy 15 year old girl had a flu-like illness two days before admission with a fluctuating level of consciousness accompanied by vomiting and extreme irritability. On admission to hospital, she was encephalopathic with no focal signs but had a marked neutrophil leucocytosis. CT showed enlarged ventricles. CSF microscopy revealed a raised white count of $60 / \mathrm{mm}^{3}$ (100\% lymphocytes) with protein $0.3 \mathrm{~g} / \mathrm{dl}$ and glucose $2.7 \mathrm{mmol} / \mathrm{l}$. The EEG was encephalopathic. She was treated during the acute phase with acyclovir, erythromycin, and cefotaxime. CSF taken on day 4 tested positive for B 19 DNA but there was insufficient sample to test for B19 antibodies. Over the next few days, she made a good spontaneous recovery but was left with significant neurological sequelae. She had poor memory for both current and distant events, became agitated very easily, and had a short temper, periods of depression, mood swings, poor concentration, slight dysphasia, a phobia about heights, panic attacks, and claustrophobia when going to sleep. She also developed Raynaud's phenomenon since the acute infection and has suffered from this ever since, with approximately two episodes a day.

Case 11

A one day old twin girl born at 23 weeks' gestation complicated by polyhydramnios had encephalitis, necrotising enterocolitis, patent ductus arteriosus, hepatitis, surfactant deficient lung disease, and osteopenia of immaturity, which later resulted in a valgus leg deformity. Following recovery from the acute phase, she had persistent hepatosplenomegaly and later developed asthma. Although she survived her development was significantly delayed. Her twin sister was not encephalopathic but suffered seizures, surfactant deficient lung disease, hemiplegia, and cerebral palsy.

CSF microscopy on day 4 revealed 14 white cells $/ \mathrm{mm}^{3}$. CSF taken on days 4 and 6 and serum taken on day 2 tested positive for B19 DNA; anti-B19 IgM was detected in both serum and CSF, while anti-B19 IgG was detected only in serum.

\section{Case 12}

A one day old girl born at 36 weeks' gestation had encephalitis, a ventricular septal defect, an atrial septal defect, a patent ductus arteriosus, poor respiratory drive, obstructive jaundice, persistent anaemia, Turner's syndrome (with a karyotype of 47XXX), multicystic kidneys, bilateral talipes, webbed toes, epicanthic folds, and hypertelorism. An ultrasound scan showed cysts on the left choroid plexus. She died on day 40 from multiple organ failure. Microscopy of CSF taken on day 20 revealed 13 white cells $/ \mathrm{mm}^{3}$, and this CSF tested positive for B19 DNA.

\section{Antiganglioside antibodies}

Serum from cases 1, 2, and 11 tested negative for antibodies to GMl, GDla, GTIb, GQlb, and sulphatides.

\section{Cytokine/chemokine testing}

Mean cytokine levels in the serum of 19 healthy normal adult controls were as follows: IL-1 $\beta$, 0; IL-5, 0; IL-6, 2.14 (range 0 to 30.91); IL-13, 0; IFN $\gamma, 0.80$ (range 0 to 8.62); TNF $\alpha, 1.62$ (range 0 to 12.32); GM-CSF, 13.73 (range 0 to 67.26); MCP-1, 0.83 (range 0 to 11.14 ).

In the cases, similar profiles of cytokine/chemokine mediators were detected in the CSF (case 1) and serum (cases 1, 2, 7 , and 11 ), in that IL-6, TNF $\alpha$, IFN $\gamma$, GM-CSF, and MCP-1 were consistently detectable while IL-1 $\beta$, IL-5, and IL-13 were consistently undetectable. Each mediator in the CSF appeared to have a value which was approximately in proportion to that in the serum. IL-6 ranged from 26.12 to $3127.87 \mathrm{pg} / \mathrm{ml}$ (mean $726.20 \mathrm{pg} / \mathrm{ml}$ ); TNF $\alpha$ ranged from 14.82 to $97.96 \mathrm{pg} / \mathrm{ml}$ (mean 50.64); IFN $\gamma$ ranged from 9.61 to $117.14 \mathrm{pg} / \mathrm{ml}$ (mean 39.64 $\mathrm{pg} / \mathrm{ml}$ ); GM-CSF ranged from 52.10 to 443.34 (mean 216.12 $\mathrm{pg} / \mathrm{ml}$ ); and MCP-1 ranged from 43.40 to $325.93 \mathrm{pg} / \mathrm{ml}$ (mean $154.43 \mathrm{pg} / \mathrm{ml}$ ) (table 3).

\section{HLA-DR testing}

Cases 1, 2, 4, 5, and 10 were typed for HLA-DRB 1 alleles. These were as follows: case $1,{ }^{*} 0404 /{ }^{*} 14$; case $2,{ }^{*} 13 /{ }^{*} 15$; case $4,{ }^{*} 04$; case $5,{ }^{*} 0403 /{ }^{*} 07$; case $10,{ }^{*} 0401 /{ }^{*} 03$ (table 1 ). 
Table 3 Cytokine concentrations $(\mathrm{pg} / \mathrm{ml})$ in serum and cerebrospinal fluid (CSF) in four cases of B 19 meningoencephalitis

\begin{tabular}{|c|c|c|c|c|c|c|c|c|c|c|c|c|}
\hline $\begin{array}{l}\text { Case } \\
\text { No }\end{array}$ & Sex & $\begin{array}{l}\text { Age } \\
\text { (gestation) }\end{array}$ & Sample & $\begin{array}{l}\text { Sample taken } \\
\text { (days post onset) }\end{array}$ & IL-1 $\beta$ & IL-5 & IL-13 & IL-6 & TNF $\alpha$ & $\mathrm{IFN} \gamma$ & GM-CSF & MCP-1 \\
\hline 1 & $M$ & $2 \mathrm{~m}$ & $\begin{array}{l}\text { CSF } \\
\text { Serum }\end{array}$ & $\begin{array}{l}3 \\
15\end{array}$ & $\begin{array}{l}- \\
-\end{array}$ & $\begin{array}{l}- \\
-\end{array}$ & $\begin{array}{l}- \\
-\end{array}$ & $\begin{array}{l}26.12 \\
79.86\end{array}$ & $\begin{array}{l}14.82 \\
69.36\end{array}$ & $\begin{array}{l}9.61 \\
27.46\end{array}$ & $\begin{array}{l}292.51 \\
52.10\end{array}$ & $\begin{array}{l}325.93 \\
43.40\end{array}$ \\
\hline 2 & $M$ & $2 \mathrm{~m}$ & $\begin{array}{l}\text { Serum } \\
\text { Serum }\end{array}$ & $\begin{array}{l}8 \\
15\end{array}$ & $\begin{array}{l}- \\
-\end{array}$ & $\begin{array}{l}- \\
-\end{array}$ & $\begin{array}{l}- \\
-\end{array}$ & $\begin{array}{l}129.24 \\
-\end{array}$ & $\begin{array}{l}30.78 \\
32.87\end{array}$ & $\begin{array}{l}53.28 \\
17.09\end{array}$ & $\begin{array}{l}193.67 \\
133.96\end{array}$ & $\begin{array}{l}279.91 \\
112.07\end{array}$ \\
\hline 7 & $M$ & $9 y$ & Serum & 13 & - & - & - & 3127.87 & 58.06 & 13.24 & 181.16 & 74.40 \\
\hline 11 & $\mathrm{~F}$ & $1 d(23 w k)$ & Serum & 2 & - & - & - & 267.89 & 97.96 & 117.14 & 443.34 & 90.88 \\
\hline
\end{tabular}

d, days; F, female; GM-CSF, granulocyte-macrophage colony stimulating factor; IFN $\gamma ; \gamma$ interferon; IL, interleukin; $m$, months; $M$, male; MCP-1, macrophage chemoattractant protein-1; TNF $\alpha$, tumour necrosis factor $\alpha$; wk, weeks; y, years; -, not detectable.

\section{In situ hybridisation}

Positive and negative control tissues gave expected and reproducible results, while multiple sections of the CNS of deceased patients 3 and 6 consistently tested negative for B19 DNA (table 2).

\section{DISCUSSION}

In this study we describe the clinical, radiological, and pathological features of parvovirus B19 associated meningoencephalitis. Involvement of the cerebellum was suggested either clinically or pathologically in four cases. Cases 5 and 9 suffered ataxia, while cases 3 and 6 had distinct cerebellar involvement at necropsy. Cerebellar ataxia has been reported in one other case of human B19 meningoencephalitis, ${ }^{5}$ and is a feature of parvovirus encephalitis in various animals. ${ }^{6-8}$

Brain scan appearances are usually normal during acute viral encephalitis'; however, several patients had abnormal magnetic resonance imaging in the present study, and this investigation provided important prognostic information as the patients with demyelination, cerebral atrophy, and abnormal white matter signals on MRI suffered long term neurological sequelae. Demyelination is a recognised feature of viral CNS infection and is believed to be caused by an inappropriate immune response to the virus. ${ }^{10}$

The mechanism by which parvovirus B19 causes CNS damage is not clear. Parvovirus B19 appears to be able to infect (and possibly replicate in) cells of endothelial and macrophage/microglial origin. ${ }^{11}$ However, several groups, including our own, have been unable to detect B19 virus in the brain in cases of B19 associated meningoencephalitis, suggesting that it is an inappropriate host immune response rather than direct viral cytotoxicity that leads to neurological symptoms and neuronal cell loss in this condition. It is important to mention here that, of those cases of B19 associated meningoencephalitis tested, B19 DNA is almost invariably detected in the $\mathrm{CSF}$ - an interesting exception being a single case of B19 associated cerebellar ataxia. ${ }^{5}$

It is known that the cutaneous manifestations of B19 infection coincide with the appearance of specific IgG in peripheral blood, suggesting that the host immune response is responsible for the characteristic B19 rash of erythema infectiosum. ${ }^{12}$ We have previously demonstrated a significant increase in proinflammatory cytokines in acute parvovirus infection and suggested that a persistent elevation of TNF $\alpha$ and IFN $\gamma$ may be associated with clinical sequelae of acute parvovirus infection. ${ }^{3}$ In the present study, we show increased levels of TNF $\alpha$, IFN $\gamma$, IL-6, MCP-1, and GM-CSF in the serum and CSF of cases of B19 meningoencephalitis, compared with low or undetectable levels of these mediators in the serum of normal controls. Inappropriate cytokine activation may play a role in the pathogenesis of other human viral CNS infections such as HIV-1 encephalopathy. ${ }^{13}$ It is possible that disturbance of the cytokine network may play a role in B19 meningoencephalitis, although the identity of relevant cytokines involved in demyelination remains to be determined as there was insufficient serum and CSF for cytokines to be determined in these cases.

Further support for the role of the immune system in B19 associated meningoencephalitis is provided by the fact that in case 2 steroids led to remission-as previously reported ${ }^{14}$ with relapse when stopped, and that intravenous immunoglobulin treatment led to complete resolution after a six week course.

We have recently shown that over $90 \%$ of patients with acute symptomatic parvovirus B19 carry DRB1*01, *04, and ${ }^{*} 07$ alleles, and that the prevalence of each of these alleles in this group is significantly more common than in the general population within the same region. ${ }^{15}$ This may be related to a charge similarity within the first hypervariable region, and would therefore include additional alleles such as *09, * 15 , and *16. Notably, other amino acid mutations within this region have been shown to mediate susceptibility to demyelinating polyneuropathy in plasma cell dyscrasia. ${ }^{16}$ Of those five patients who were HLA-DR typed in the present study, four carried at least one HLA-DRB1*01, *04, *07 allele, while one was HLA-DRB1*13/*15. Although we do not provide HLADRBl data for cases of viral meningoencephalitis, which would be desirable for comparison, these data show that those HLA-DRBI alleles associated with symptomatic parvovirus B19 infection ${ }^{15}$ are also associated with B19 associated meningoencephalitis.

\section{Conclusions}

We have reviewed the clinical and pathological features in 12 cases of parvovirus B19 associated meningoencephalitis. We have shown that cerebellar involvement is a feature, that MRI may provide prognostic information, and that in view of the cytokine dysregulation and possible restriction of the major histocompatibility complex in this disease, the immune system is likely to play an important role in the pathogenesis. This is further supported by the beneficial effect of steroids and intravenous immunoglobulin treatment in one case. Further work is required to confirm these conclusions, as this report is based on a small number of cases for which the data are incomplete.

\section{ACKNOWLEDGEMENTS}

We thank Mr Alex Liversage of BioRad, UK, for assistance with cytokine testing protocols and Dr Derek L Mattey for advice on discussion of HLA-DRBl alleles.

\section{Authors' affiliations}

J R Kerr, Department of Microbiology, Royal Brompton and Harefield NHS Trust, Imperial College School of Medicine, London, UK

J Smith, Department of Tissue Typing, Royal Brompton and Harefield 
NHS Trust

M N Sheppard, Department of Histopathology, Royal Brompton and Harefield NHS Trust

F Barah, Department of Virology, University of Manchester, Manchester, UK

M L Chiswick, Neonatal Medical Unit, St Mary's Hospital, Manchester, UK

G V McDonnell, Department of Neurology, Royal Group of Hospitals, Grosvenor Road, Belfast, UK

M D Chapman, Department of Neuroimmunology, National Hospital for Neurology and Neurosurgery, London, UK

J B Bingham, Departments of Radiology, Guy's and St Thomas's NHS

Trust, London, UK

P Kelleher, Department of Immunology, Wright-Fleming Institute, Imperial

College London, UK

Competing interests: none declared.

\section{REFERENCES}

1 Barah F, Vallely PJ, Chiswick ML, et al. Association of human parvovirus B19 infection with acute meningoencephalitis. Lancet 2001;358:72930.

2 Weiner SM, Klein R, Berg PA. A longitudinal study of autoantibodies against central nervous system tissue and gangliosides in connective tissue diseases. Rheumatol Int 2000;19:83-8.

3 Kerr JR, Barah F, Mattey DL, et al. Serum tumour necrosis factor- $\alpha$ (TNF- $\alpha$ ) and interferon- $\gamma$ (IFN- $\gamma$ ) are detectable during acute and convalescent parvovirus B 19 infection and are associated with prolonged and chronic fatigue. J Gen Virol 2001;82:3011-19.

4 Hicks KE, Cubel RCN, Cohen BJ, et al. Sequence analysis of a parvovirus B19 isolate and baculovirus expression of the non-structural protein. Arch Virol 1996;141:1319-27.

5 Shimuzu Y, Ueno T, Komatsu $H$, et al. Acute cerebellar ataxia with human parvovirus B19 infection. Arch Dis Child 1999;80:72-3.
6 Oster-Granite ML, Herndon RM. The pathogenesis of parvovirus-induced cerebellar hypoplasia in the Syrian hamster, Mesocricetus auratus. Fluorescent antibody, foliation, cytoarchitectonic, Golgi and electron microscopic studies. J Comp Neurol 1976;169:481-521

7 Ramirez JC, Fairen A, Almendral JM. Parvovirus minute virus of mice strain I multiplication and pathogenesis in the newborn mouse brain are restricted to proliferative areas and to migratory cerebellar young neurons. J Virol 1996;70:8109-16

8 Siegl G, Cassinotti P. Parvoviruses. In: Collier L, Balows A, Sussman M, eds. Topley \& Wilson's microbiology and microbial infections, vol 1. London: Arnold, 1998:261-79.

9 Mitomo M, Hosoki T, Sai H, et al. Radiological diagnosis of viral encephalitis. Nippon Rinsho 1997:55:815-21.

10 Stohlman SA, Hinton DR. Viral induced demyelination. Brain Pathol 2001;11:92-106.

11 Isumi H, Nunoue T, Nishida A, et al. Fetal brain infection with human parvovirus B 19. Pediatr Neurol 1999;21:661-3.

12 Anderson MJ, Higgins PG, Davis LR, et al. Experimental parvoviral infection in humans. J Infect Dis 1985;152:257-65.

13 Mintz M, Rapaport R, Oleske JM, et al. Elevated serum levels of TNF are associated with progressive encephalopathy in children with acquired immunodeficiency syndrome. Am J Dis Child 1989;143:771-4.

14 Druschky K, Walloch J, Heclanann J, et al. Chronic parvovirus B19 meningoencephalitis with additional detection of Epstein-Barr virus DNA in the cerebrospinal fluid of an immunocompetent patient. J Neurovirol 2000;6:418-22.

15 Kerr JR, Mattey DL, Thomson W, et al. Association of symptomatic acute parvovirus B19 infection with HLA class I and class II alleles. J Infect Dis 2002; 186:447-52.

16 Vrethem M, Ernerudh J, Cruz M, et al. Susceptibility to demyelinating polyneuropathy in plasma cell dyscrasia my be influenced by amino acid position 9 of the HLA-DR beta chain. J Neuroimmunol 1993;43:139-44.

\section{NEURONLINE}

\section{PubMed: http://www.pubmed.org}

F

st, library shelves groaned under the weight of volume after volume of Index Medicus. Then came Medline, a journal abstracting and search service initially available on CD (at a price) and, for the UK higher education community, by telnet and then on the web ... and then there was PubMed.

It is a mark of its success that it already seems to have been with us forever ... but it is only 5 years since former American Vice President Al Gore, in a breathtaking act of generosity, announced free interne access to PubMed. In a world where knowledge is increasingly viewed as a commodity (viz the human genome project) PubMed demonstrates the global power of the internet to transform access to information.

So what can it do? PubMed now contains more than 12 million citations (about a million more than Medline), and search fields include Medical Subject Heading (MeSH) keyword and title or abstract word or phrase. The search returns a full citation including an abstract of the article and, increasingly, a hyper-text link to where the article may be obtained online. In a recent PubMed search I had immediate full text access for 16 of 20 "hits". The department photocopier will soon be obsolete, and in many respects the library already is.

There are some drawbacks. Firstly, citation searching is not available (but see www. mimas.ac.uk), so looking forward from important papers is not possible. Secondly, abstracts on your computer may seem as

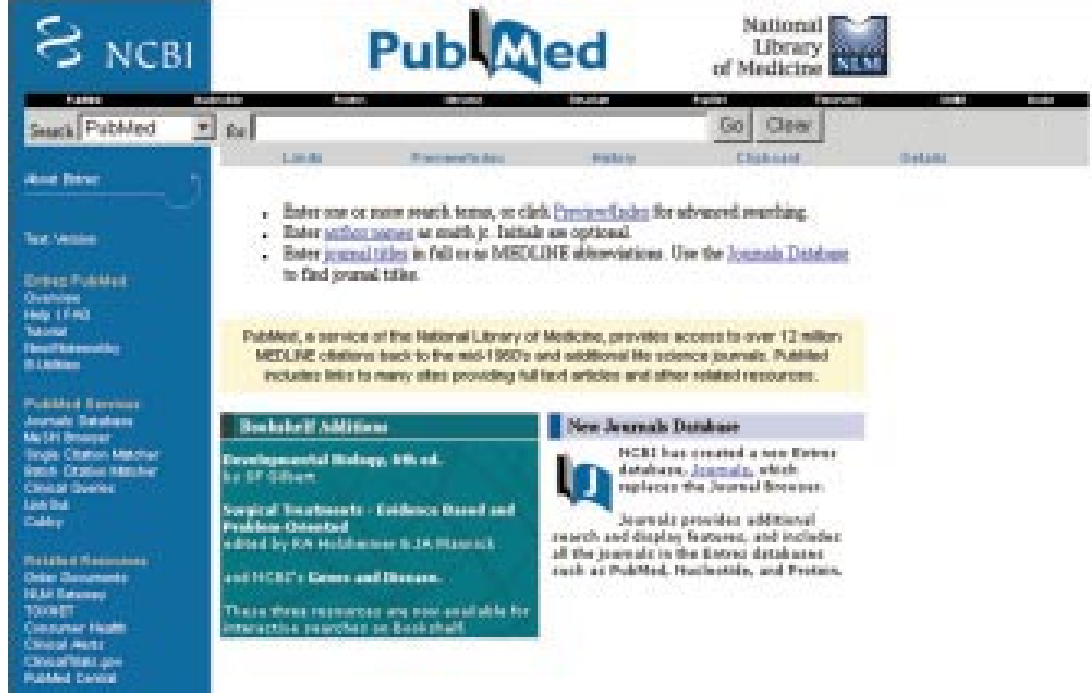

reliable as full text articles in a library across town, encouraging a superficial engagement with the literature.

Finally, PubMed can be a (dubious) source of diagnostic assistance: searching for "case report", "deafness", "retinitis pigmentosa", and "myopathy", for instance, returns only 24 hits, most of which describe a mitochondrial disease. Comparison of this approach with a more traditional line of diagnostic attack has yet to be subjected to a randomised controlled trial.

M R Macleod

Department of Clinical Neurosciences, Western General Hospital, Crewe Road, Edinburgh EH4 2XU, UK; malcolm@apoptosis.freeserve.co.uk 